\title{
Wood-cement-composite behaviour of beech circular hollow sections
}

\author{
Sebastian Hirschmüller ${ }^{1}\left(\mathbb{C} \cdot\right.$ Seraphin Hubert Unterberger ${ }^{2} \cdot$ Roman Marte $^{3} \cdot$ Jan-Willem van de Kuilen ${ }^{4}$
}

Received: 15 October 2019 / Accepted: 5 November 2020 / Published online: 24 November 2020

(c) The Author(s) 2020

\begin{abstract}
Beech laminated veneer lumber (LVL) circular hollow sections for use as nails in temporary geotechnical soil nailing systems were developed within this research. For the soil wall stability, beside a sufficient load carrying capacity of the nail cross section, a load carrying connection between the cement annulus and the nail is necessary. As cement grout ensures the bond between the nails and soil for the mobilisation of a soil reinforcement effect, a reliable connection between cement and wood surface is required. Occurring shear forces must be transferred from the nail into the soil through the wood-cement interface similar to reinforced concrete. Pull-off tests on clear LVL specimens with different cement and wood surface modifications as well as the results of large-scale push-out tests are presented. The results reveal a sufficient short-term bonding strength between the cement annulus and the wooden member to transfer the geotechnical loads, but also highlight the necessity of further research on long-term behaviour.
\end{abstract}

\section{Introduction}

Temporary soil nailing systems, or reinforced soil walls (RSW), are often used to stabilize excavation slopes. Typically, steel nails are drilled into the soil followed by filling up the annulus around the steel using cement grout. The cement protects the steel against corrosion and ensures the

Sebastian Hirschmüller

sebastian.hirschmueller@th-rosenheim.de

Seraphin Hubert Unterberger

seraphin.unterberger@uibk.ac.at

Roman Marte

roman.marte@tugraz.at

Jan-Willem van de Kuilen

vandekuilen@hfm.tum.de

1 Department of Research and Development, Technical University of Applied Sciences Rosenheim, Hochschulstraße 1, 83024 Rosenheim, Germany

2 Institute of Construction and Material Sciences, Material Technology, University of Innsbruck, Technikerstraße 13, 6020 Innsbruck, Austria

3 Institute of Soil Mechanics, Foundation Engineering and Computational Geotechnics, Graz University of Technology, Rechbauerstraße 12, 8010 Graz, Austria

4 Civil, Geo and Environmental Engineering, TUM School of Life Sciences, Holzforschung München, Technical University of Munich, Winzererstraße 45, 80797 München, Germany necessary connection between soil and nail. Afterwards a reinforced shotcrete layer is attached to protect the slope's surface. Wood and engineered wood products have a long tradition as structural elements in geotechnical slope stabilizations and are still part of new constructions. It is an obvious but innovative approach to use biodegradable nails made of renewable materials for temporary soil nailing, rather than wasting valuable but primary energy intense raw materials such as tempered steel.

The possibility of substituting temporary steel nails by laminated veneer lumber (LVL) hollow cross sections (Fig. 1), manufactured from European beech (Fagus sylvatica $L$.), is being investigated in a research project aimed to develop a sustainable temporary RSW system. The geotechnical background for the cross section choice and detailed information about the LVL layer structure are given in Hirschmüller et al. (2018a, b). In the geotechnical design of RSWs, the nail load bearing capacity is inter alia determined by the mobilised skin friction between cement annulus and soil and must be verified through pull-out tests of nails compliant to EN 14490: (2010). Therein, the bonding behaviour between steel and cement annulus is assumed to be rigid as in the design of reinforced concrete, which is widely investigated and manifested in European and national standards (Ritter 2013; Zilch and Zehetmaier 2010). However, when using beech LVL hollow sections as reinforcement members for RSWs, because of its excellent peeling performance and its higher strength compared to softwoods, a reliable and 


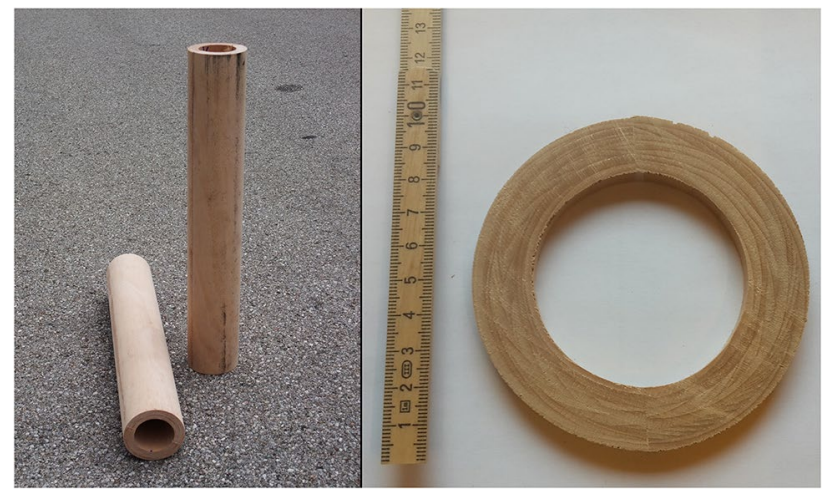

Fig. 1 Beech LVL hollow sections prototypes (left) and related cross section with $100 \mathrm{~mm}$ outer diameter and $18 \mathrm{~mm}$ wall thickness

rigid connection between the nail and the cement annulus has to be ensured. Occurring shear forces have to be transferred from the nail into the soil through the wood-cement composite, similar to corrugated steel in reinforced concrete works. Two main groups of wood-cement composites can be distinguished and have been intensively investigated within the last decades. Material compounds of wood particles and cement are successfully utilized as combined particleboards, wood-wool slabs and concrete with wooden aggregates. Expensive steel and a high amount of bamboo plantations in Asiatic regions led to an increased utilization of bamboo rods as reinforcement members in concrete, ensuring the bond between bamboo and concrete by cohesion, surface friction and an interlocking mechanism between concrete and the bamboo nodes (Azadeh and Kazemi 2014).

Within the timber-concrete system, the materials wood and cement are interacting. Beech LVL-hollow sections permanently exposed to an alkaline medium due to the subsoil installation and the cement embedment of the nails, reveal a considerable loss of material strength due to the alkaline degradation of wood (Glaus et al. 1999; Hirschmüller et al. 2018b; Knill and Kennedy 2003; Mašura 1982; Tamburini 1970). Extracted organic wood components, in particular beech, have a high amount of water-soluble sugars and therefore, reveal an inhibiting effect on the cement hydration, resulting in a retarded reaction time, having a reduced maximum hydration temperature (Wei et al. 2000b) and a lower strength of hardened cement paste (Schubert et al. 1990a). Research in the field of wood/cement interaction has shown that cement composition (e.g., use of low-alkali cements), usage of cement admixtures (e.g., chemical cement setting accelerators) and pre-treatment of wood (e.g., steaming, hydro extraction, sodium hydroxide extraction or cement micro coating) help to compensate the abovementioned cement hydration inhibiting effect (Klatt 2012; Schubert et al. 1990a, 1990b; Schwarz and Simatupang 1984; Simatupang 1986; Wei et al. 2000a).
Most investigations into structural hybrid elements such as timber-concrete composite flooring systems focus on structural aspects like load bearing capacity, improvement of shear connections or fire resistance (Klingsch et al. 2015). Contrary to the development of particleboards, wood-wool slabs or concrete with wooden aggregates, the inhibiting effect of solved polysaccharide on cement hydration in hybrid elements is neglected, due to the lower contact area of wood and cement compared to wood-cement composites containing wood chips, strands or particles. Only a thin cement layer at the interface between timber and cement is disturbed and does not significantly affect the bonding between timber and concrete, due to the mechanical or form-locked connection using steel fasteners, corrugations or notches of $15 \mathrm{~mm}$ depth and even more. Interface hydration investigations of Portland cement in contact with spruce, beech and birch boards (Simatupang 1986) support this assumption of a very thin, loose cement layer, due to the low amount of loose cement observed on the wood surface after $48 \mathrm{~h}$ hydration and subsequent removal of the hardened cement.

The development of a high-engineered wood-cement composite product, utilized as geotechnical reinforcement element, demands a cost-effective product configuration with regard to the comparable low-priced mass product steel. Thus, a shear-resistant connection between reinforcement member and beech LVL hollow section has to be ensured, but additional and unnecessary processing steps during production have to be minimized. Beside economical aspects, mechanical fasteners or surface corrugations for a form-locked connection between the cement annulus and the beech LVL hollow section reduce the net cross section and therefore decrease the load bearing capacity of the reinforcement member. Hence, full-surface adhesive bonding is a possible way to overcome this problem. However, only little information is available about the adhesion between wood and concrete of timber-concrete composites without mechanical fasteners or form-locked connections. In Schober (2008), an excellent and rigid adhesion bond between softwood and polymer concrete depending on the wood surface structure is reported. However, since the bonding connection between softwood and concrete is ensured by the polymer concrete's epoxy resin binder, the system is not comparable to concrete composites with mineral binders. A promising load bearing capacity of full-surface adhesion bonded structural floorings made of rafted softwood decks with mineral overlay is presented in Lehmann (2005), but the results cannot be transferred to other wood species, especially beech, due to the stronger cement hydration inhibiting effects of hardwoods compared to softwoods (Simatupang 1986).

The presented research focuses on the development of a sufficient full-surface bonding between beech LVL hollow sections, utilized for soil nailing reinforcement, and the 
cement annulus in order to assure a reliable transfer of shear forces between soil and reinforcement nail. Firstly, the paper introduces the investigated composite's cross section and the associated surface modification process of the LVL hollow sections. As in published research work, mainly the maximum cement hydration temperature, its temporal position and the compressive strength of hardened cement samples mixed with wood eluate water or wood chips are of interest (Schubert et al. 1990a, b; Schwarz and Simatupang 1984), only little information about the hydration inhibiting effect of wooden boards with cement contact, examined by a determination of loose cement material remaining on the contact surface, is available (Simatupang 1986). However, to the authors' knowledge, no publication deals with the surface soundness determination of cement in contact with peeled beech veneer. Therefore, preliminary pull-off tests on small LVL specimens with different cement and wood modifications are presented. Finally, results of large-scale push out tests, similar to a test setup published in Lopez-Anido et al. (2004), are analysed and discussed. The performance of three different surface modifications in relation to the surface roughness is compared to occurring average bond stresses in usual RSW's up to $6 \mathrm{~m}$ slope height, $\mathrm{H}_{\mathrm{S}}$, consisting of steel tensile members.

\section{Materials and methods}

\subsection{Materials}

\subsubsection{Wood}

For the production of the outer veneer layer (veneer layer with surface contact to the cement body) of the circular LVL hollow sections and the LVL flat panels, one log of beech wood (Fagus sylvatica L.), $800 \mathrm{~mm}$ long and approximately $450 \mathrm{~mm}$ in diameter and free of knots was harvested in Kirchdorf in Tirol (AT). The log was steamed at $80{ }^{\circ} \mathrm{C}$ and atmospheric pressure for $24 \mathrm{~h}$ in a steaming chamber and then peeled to $3 \mathrm{~mm}$ thick veneers. Immediately after cutting to sheets with dimensions of $800 \mathrm{~mm}$ by $800 \mathrm{~mm}$, the veneer sheets were visually graded by surface appearance according to EN 635-2 (1995). Only veneers assigned to EN 635-2: (1995) quality class E were used for further testing and mixed in order to avoid a non-random influence of raw-density $\rho_{\mathrm{N}}$ (volumetric mass density, determined at an equilibrium wood moisture content $\mathrm{u}_{\mathrm{gl}}$ after storage at $20{ }^{\circ} \mathrm{C}$ and $65 \%$ relative humidity until constant weight) and other wood characteristics. Therefore, a statistically randomly distributed basic population of veneer sheets was formed. Prior to veneer drying of all peeled veneers for $48 \mathrm{~h}$ in a veneer drying system, randomly chosen veneers were taken from the basic population and surface corrugated as described in the section "Methods". Subsequently, all dried and surface corrugated veneer sheets were cut into stripes of $200 \mathrm{~mm}$ width and $800 \mathrm{~mm}$ length (parallel to the fiber direction). After storing the pre-sized veneer sheets in normal climate (NC) of $20{ }^{\circ} \mathrm{C}$ and $65 \%$ relative humidity (RH) until constant weight $\left(\mathrm{u}_{\mathrm{gl}} \approx 11.3 \%\right), \rho_{\mathrm{N}}$ of each veneer stripe was measured. For the production of the inner veneer layers (not in cement contact), $3 \mathrm{~mm}$ thick veneer sheets of dimensions $800 \mathrm{~mm} \times 1400 \mathrm{~mm}$, provided free of charge from "Sperrholzwerk Schweitzer GmbH" in St. Marienkirchen/ Polsenz (Austria), were used and processed as described in Hirschmüller et al. (2018b), but without further veneer grading or determination of $\rho_{\mathrm{N}}$.

\subsubsection{Cement and cement additive}

For all investigations, a cement type CEM II/ A-M (S-LL) $42.5 \mathrm{~N}$ was used. Practically, in soil nailing a cement suspension with a rather high water to cement ratio $(w / c=0.6)$, instead of liquefier addition, is used, due to the better pumpability and the lower costs. In the preliminary pull-off experiments for surface soundness testing, magnesium chloride hexahydrate $\left(\mathrm{MgCl}_{2} \cdot 6 \mathrm{H}_{2} \mathrm{O}\right.$; molar mass $\left.\mathrm{M}_{\mathrm{r}}=203.3 \mathrm{~g} / \mathrm{mol}\right)$ was added to the cement in portions of $1 \%, 2 \%, 3 \%$ and $4 \%$ (referred to dry cement weight) for the acceleration of the cement setting.

\subsection{Methods}

\subsubsection{Veneer surface corrugation}

The veneer surface of the outer LVL hollow section layer adjacent to the cement body was modified by stamping corrugations into the surface on the heartwood side (veneer side with open peeling cracks) of the veneer sheets, using an aluminium bulb plate punch (dimensions $600 \mathrm{~mm} \times 600 \mathrm{~mm}$ ) with $1 \mathrm{~mm}$ high quintet patterns (Fig. 2a) compliant to EN 1386 (2007). For press stress application, the differently treated $200 \mathrm{~mm}$ wide and $500 \mathrm{~mm}$ long (in fibre direction) peeled beech veneers were inserted in a commercial veneer press with $120{ }^{\circ} \mathrm{C}$ hot pressure plates (Fig. 2b) and a vapour pressure equalising layer upon the bottom plate. To investigate the different wood plasticisation modes during hot pressing, five corrugation series of preliminary wood treatment with different veneer conditioning and press stresses were developed (Table 1). As it is industrially difficult to process veneer punching subsequent to the peeling process, two batches (batch 1 and 2) of surface corrugations with veneers of the same basic population, stored for 20 days in NC, were produced. Veneer sheets were punched without any preliminary wood plasticisation (batch 1 , climate NC). Additionally, previously NC stored dry veneer sheets were placed for $2 \mathrm{~h}$ in a $\log$ steaming chamber at $80{ }^{\circ} \mathrm{C}$ air 
Fig. 2 Veneer surface corrugation. a Aluminium bulb plate with $1 \mathrm{~mm}$ high quintet pattern, b open veneer press with inserted veneer sheet and at the bottom plate vapour pressure equalising layer
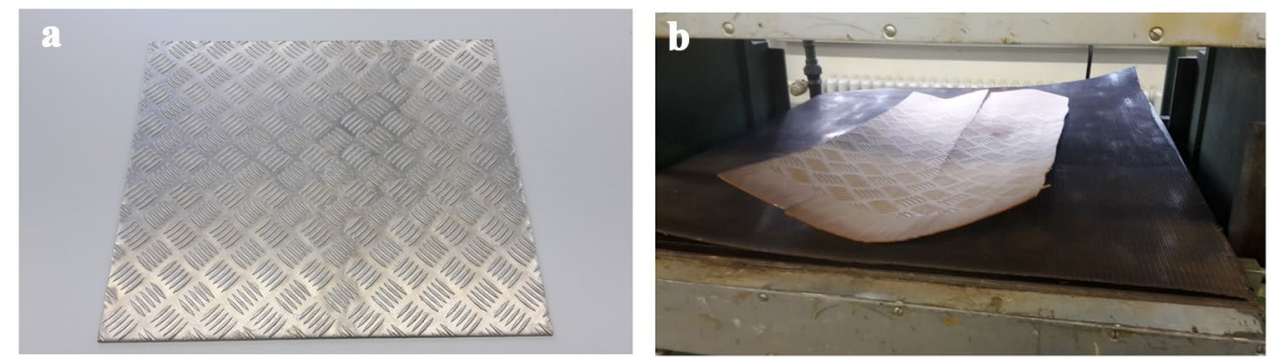

Table 1 Veneer surface corrugation series

\begin{tabular}{lllllll}
\hline $\begin{array}{l}\text { Batch } \\
{[-]}\end{array}$ & $\begin{array}{l}\mathrm{n} \\
{[-]}\end{array}$ & $\begin{array}{l}\rho_{\mathrm{N}} \\
{\left[\mathrm{kg} / \mathrm{m}^{3}\right]}\end{array}$ & $\begin{array}{l}\mathrm{T} \\
{\left[{ }^{\circ} \mathrm{C}\right]}\end{array}$ & $\begin{array}{l}\text { Press stress } \\
{[\mathrm{MPa}]}\end{array}$ & $\begin{array}{l}\text { Climate }^{\mathrm{a}} \\
{[-]}\end{array}$ & $\begin{array}{l}\text { Press time } \\
{[\mathrm{min}]}\end{array}$ \\
\hline 1 & 4 & 637 & 120 & 1.5 & $\mathrm{NC}$ & 3 \\
2 & 9 & 634 & 120 & 1.5 & STEAM & 3 \\
3 & 10 & 558 & 120 & 1.5 & $\mathrm{P}>40$ & 3 \\
4 & 7 & 562 & 120 & 1.5 & $\mathrm{P}<40$ & 3 \\
5 & 6 & 548 & 120 & 1.0 & $\mathrm{P}<40$ & 3 \\
\hline
\end{tabular}

a Explanation: $n$ number of veneer sheets with surface corrugation, $N C$ veneers stored in normal climate, STEAM veneers steamed, $P>40$ veneer surface corrugation later than $40 \mathrm{~min}$ after peeling, $P<40$ veneer surface corrugation at the latest $40 \mathrm{~min}$ after peeling temperature and atmospheric pressure (batch 2, climate STEAM) prior to punching. The surface of the fresh-peeled and plastified beech veneer batches (due to wood plasticisation by log steaming prior to rotary cut veneer peeling as described in the section "Materials") was punched subsequent to peeling and pre-sizing, whereby the series were distinguished in

- Batch 3: Surface punching of veneers more than $40 \mathrm{~min}$ after peeling $(\mathrm{P}>40)$

- Batch 4: Surface punching of veneers not later than 40 min after peeling $(\mathrm{P}<40)$

- Batch 5: Surface punching of veneers not later than 40 min after peeling but with lower press stress (1.0 MPa).

After punching and subsequent storage in $\mathrm{NC}$ for 20 days, $\rho_{\mathrm{N}}$ of all veneers was determined.

\subsubsection{Flat panel production}

Four flat LVL panels (approximately $200 \mathrm{~mm}$ wide, $18 \mathrm{~mm}$ thick and $800 \mathrm{~mm}$ long parallel to the fibre direction of the sheets), which consisted of six layers $3 \mathrm{~mm}$ thick and unidirectionally adjusted peeled beech veneer sheets, were produced. The upper veneer layer of the panels (veneer in direct cement contact) was randomly chosen from the previously formed veneer basic population, but without any previous veneer surface treatment or veneer surface modification. The core side of the upper veneer layer was faced towards the cement layer. For the remaining five inner layers, ungraded veneers without any classification were used. The panels were bonded using a melamine-urea-formaldehyde resin MUF (BASF Kauramin 683 with hardener 688), whereby the specific processing parameters are published in Hirschmüller et al. (2018a). Before cutting the four panels to $18 \mathrm{~mm}$ thick pieces of dimensions $65 \mathrm{~mm} \times 65 \mathrm{~mm}$, the panels were stored again in NC for at least 7 days (curing time recommended by the adhesive manufacturer). To exclude the influence of the surface roughness on the bonding strength between wood and cement, two of the four panels were planed and equalized on both sides before cutting. Subsequently, two groups of 60 panel pieces and 45 panel pieces, respectively, with dimensions of $65 \mathrm{~mm} \times 65 \mathrm{~mm}$, were formed. Thus, the veneer surface of one group was planed, the other group had an untreated, original veneer surface.

\subsubsection{Surface soundness (pull-off experiments)}

The surface soundness between wood panels and cement was tested using a pull-off test method modified according to EN 311 (2002) and also applied in other publications on hybrid materials testing (Lehmann 2005; Schober 2008; Unterberger 2014). The two previously prepared groups of flat LVL panel pieces were divided into seven batches with 15 panels each (Table 2). The flat LVL panels with planed veneer surface were used for cement modification tests with varying cement additive proportions, but constant wood moisture content at $\mathrm{u}_{\mathrm{gl}}$. The panels with an 
Table 2 Overview of pull-off experiment batches

\begin{tabular}{llllllll}
\hline $\begin{array}{l}\text { Batch }^{\mathrm{a}} \\
{[-]}\end{array}$ & $\begin{array}{l}\mathrm{n} \\
{[-]}\end{array}$ & $\begin{array}{l}\mathrm{MgCl}_{2} \\
{[\%]}\end{array}$ & $\begin{array}{l}\mathrm{A}_{\mathrm{CEM}} \\
{\left[\mathrm{mm}^{2}\right]}\end{array}$ & $\begin{array}{l}\mathrm{MC} \\
{[\%]}\end{array}$ & $\begin{array}{l}\text { Veneer surface } \\
{[-]}\end{array}$ & $\begin{array}{l}\text { Setting time } \\
{[\mathrm{d}]}\end{array}$ & $\begin{array}{l}\text { w/c } \\
{[-]}\end{array}$ \\
\hline 1 & $15(10)$ & 1 & 1691 & 11 & Planed & 7 & 0.6 \\
2 & $15(6)$ & 2 & 1691 & 11 & Planed & 7 & 0.6 \\
3 & $15(8)$ & 3 & 1691 & 11 & Planed & 7 & 0.6 \\
4 & $15(10)$ & 4 & 1691 & 11 & Planed & 7 & 0.6 \\
5 & $15(15)$ & 4 & 1691 & 11 & Rough & 7 & 0.6 \\
6 & $15(14)$ & 4 & 1691 & 21 & Rough & 7 & 0.6 \\
7 & $15(13)$ & 4 & 1691 & 48 & Rough & 7 & 0.6 \\
REF SP & $15(14)$ & 4 & 1691 & 12 & Planed & 7 & 0.6 \\
REF LIT & $4(3)$ & - & 23,680 & 16 & Rough & 68 & 0.77 \\
REF LIT_1 & $76(76)$ & - & 1691 & - & Planed & 1 & $0.7-0.8$ \\
\hline
\end{tabular}

${ }^{a}$ Explanation: $n$ number of prepared samples. Tested samples without failure prior to testing are listed in brackets, $\mathrm{MgCl}_{2}$ amount of added magnesium chloride hexahydrate, $A_{C E M}$ veneer surface with cement contact, $M C$ average wood moisture content, ${ }^{-}$data not available, Setting time time of cement setting until pulloff testing

${ }^{\mathrm{b}}$ Literature data (Lehmann 2005)

${ }^{\mathrm{c}}$ Literature data (Unterberger 2014) unmodified and rough veneer surface were tested with a constant cement additive proportion, but varying wood moisture contents. Magnesium chloride hexahydrate $\left(\mathrm{MgCl}_{2} \cdot 6 \mathrm{H}_{2} \mathrm{O}\right.$; molar mass $\left.\mathrm{M}_{\mathrm{r}}=203.3 \mathrm{~g} / \mathrm{mol}\right)$ was added to the cement $(\mathrm{w} / \mathrm{c}=0.6)$ in proportions of $1 \%, 2 \%, 3 \%$ and $4 \%$ by mass (referred to the cement weight) as a cement setting accelerator. Additionally, 15 spruce boards with planed surface of the same dimensions as the LVL batches were produced (batch REF SP) to receive reference results of a softwood species with significantly lower hydration inhibiting potential than beech (Simatupang 1986). As to the author's knowledge no data of beech veneer surface soundness results are available in the literature, the pull-off strength of batch REF SP is validated through values of similar tests (batch REF LIT and REF LIT_1) published in Lehmann (2005) and Unterberger (2014). Therein, the pull-off strength between spruce boards and concrete mixtures compliant to EN 206 (2016) are given. After wood panel conditioning of all batches listed in Table 2 to the target wood moisture content, the cement filled PVC-tubes (inner tube diameter $\mathrm{d}=46 \mathrm{~mm}$ ) were placed on the panels from the upside (to avoid loss of contact between cement and wood due to the cement shrinkage) and subsequently stored in NC for seven days during the cement setting process (Fig. 3).

The contact area $A_{\text {CEM }}$ between veneer surface and cement can be calculated as

$\mathrm{A}_{\mathrm{CEM}}=\frac{\pi \mathrm{d}^{2}}{4}$

After seven days cement setting, all samples were carefully removed and tested in a Schenk Trebel UPM-T $20 \mathrm{kN}$

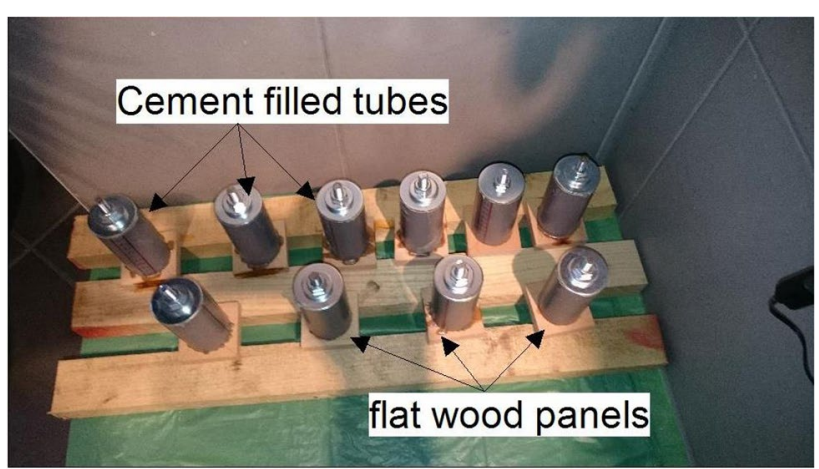

Fig. 3 Sample storage in NC during seven days cement setting

hydraulic testing machine with a constant displacement rate to reach failure within $(90 \pm 30)$ seconds (Fig. 4). A ring screw was centrically screwed into the panel surface with no cement contact for mounting the force gauge's spring to ensure a centrical loading with reduced surface peeling effects. The total load $\mathrm{F}_{\text {tot }}$ was determined by a digital force gauge (Alluris FMI100-C2) with $200 \mathrm{~N}$ measurement resolution and $\pm 0.02 \%$ measurement accuracy $\mathrm{t}_{1}$. Immediately after testing, each sample's weight force $\mathrm{G}$ was measured using a spring force gauge (Phywe 1.0) with $1 \mathrm{~N}$ measurement resolution and $\pm 0.5 \%$ measurement accuracy $t_{2}$. Therefore, the effective bonding load $\mathrm{F}_{\text {eff }}$ can be calculated as

$\mathrm{F}_{\text {eff }}=\mathrm{F}_{\mathrm{tot}}-\mathrm{G}$

and a relative measurement accuracy $t_{\text {rel }}$ (rounded off to two significant digits) 
Fig. 4 Pull-off test with schematic setup overview (right); dimensions in millimetres
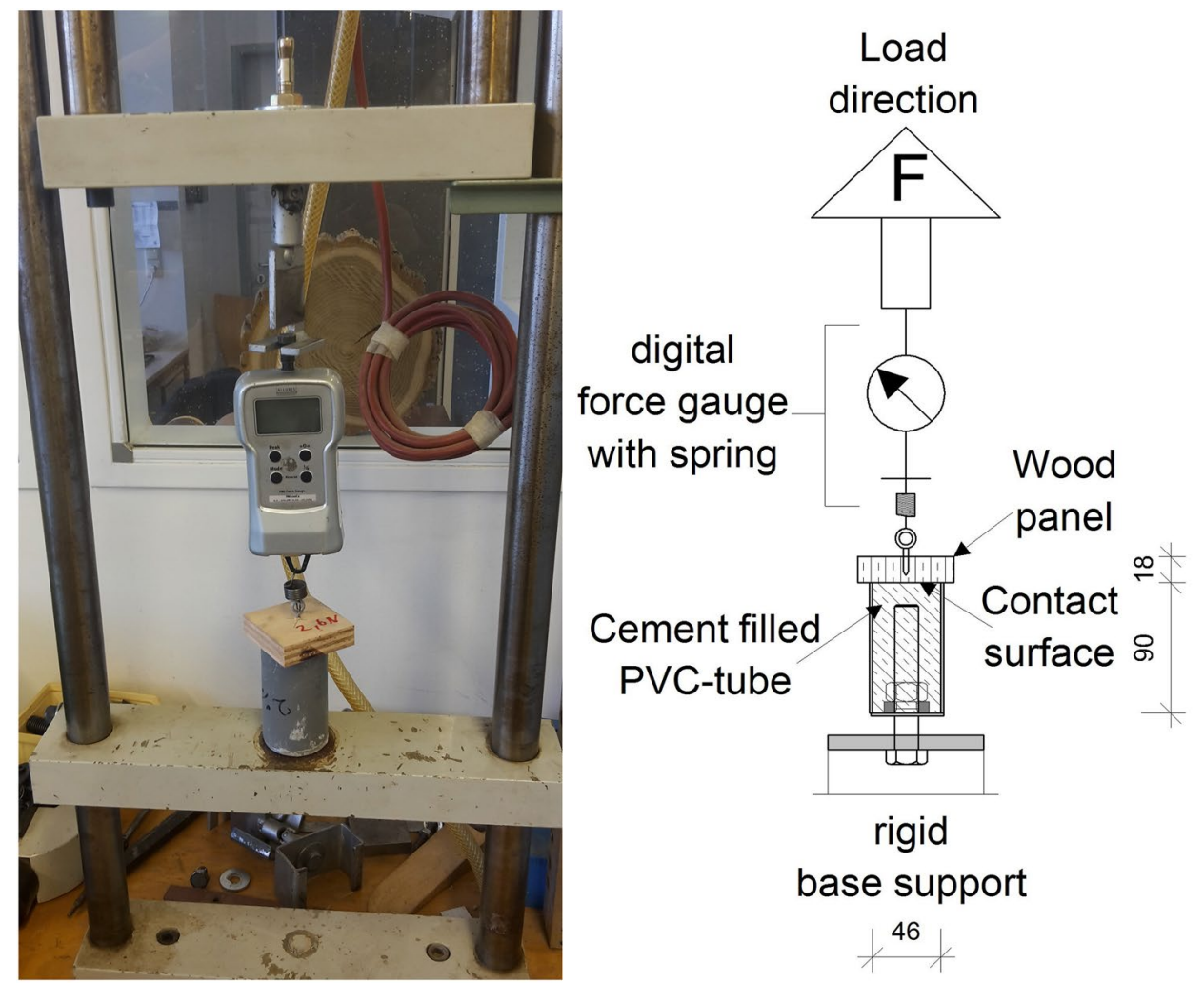

$\mathrm{t}_{\text {rel }}=\mathrm{t}_{1}+\mathrm{t}_{2}=0.5 \%$

\subsubsection{Wood surface topography measurement}

The veneer surface structure is a decisive criterion for the bonding mechanism between veneer surface and cement body, whereby macroscopically rough surfaces are assumed to support the bonding strength (Lehmann 2005). However, to provide economically efficient solutions, additional processing steps to increase the surface roughness should be avoided. Thus, comparing the surface topography of unmodified, rough veneers to veneers with surface corrugations applied in an additional processing step is inevitable for the interpretation of the push-out tests. Therefore, four randomly chosen small veneer sheets of dimensions $100 \mathrm{~mm} \times 100 \mathrm{~mm}$ were taken from each veneer surface corrugation series (Table 1). Four additional small veneer sheets of series 1 without punching were taken as reference veneer, stored in NC without any surface treatment or surface corrugation. Within an area of approximately $40 \mathrm{~mm} \times 40 \mathrm{~mm}$ on the veneer core side, the roughness was measured using a focus variation microscope (Alicona Infinite Focus G4) and an objective for 2.5 times magnification (minimum measurable centre line average roughness $R_{a}=7 \mu \mathrm{m}$ ), giving a vertical resolution of $2300 \mathrm{~nm}$ with a measurement range of $5.63 \mathrm{~mm} \times 5.63 \mathrm{~mm}$. For all five measured series consisting of four samples each, eight areal scans were made on each surface. Detailed information about the theoretical background of this surface texture measuring method is given in Leach (2011) and Nwaogu et al. (2013).

\subsubsection{LVL sample manufacturing and push-out tests}

After storing all veneers in NC until equlibrium wood moisture content (controlled by weighing), three groups of circular LVL hollow sections (CLHS), $320 \mathrm{~mm}$ long, $18 \mathrm{~mm}$ wall thickness $d$ and of $100 \mathrm{~mm}$ outer mean diameter $\mathrm{D}_{\mathrm{m}}$, were produced. All CLHS were produced in a tapered shape (Fig. 5) with $4 \mathrm{~mm}$ difference between the end diameters. The manufacturing process of the CLHS, developed and published in Hirschmüller et al. (2016, 2018a,b), was used to produce the investigated samples. For the bonding of the half cross-sections as well as the but jointing of the two half poles to a full CLHS, a melamine-urea-formaldehyde resin MUF (BASF Kauramin 683 with hardener 688) was used. The same processing parameters as for the production of the flat pull-off panels were used. The grain direction of all veneers was adjusted to the pole axis; no transverse layers were used. The core side of all veneers (veneer side with open peeling cracks) was faced towards the outside of the cross section. Three batches with different surface modifications, consisting of 57 samples in total, were produced 


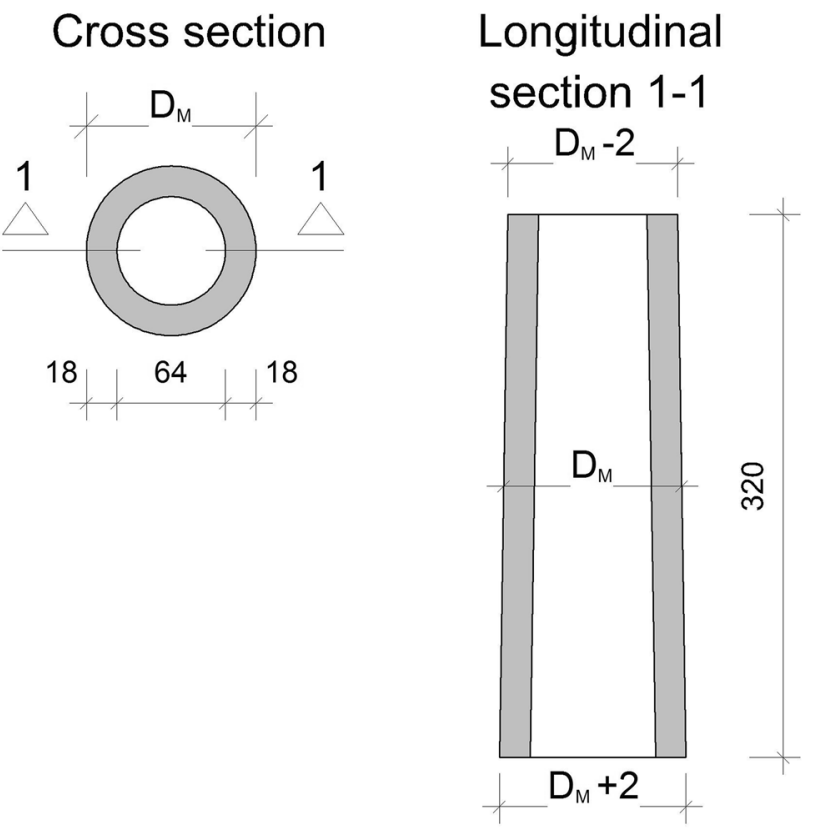

Fig. 5 Schematic LVL hollow cross section (left) and longitudinal section (right); dimensions in millimetres

Table 3 Overview of CLHS batches

\begin{tabular}{|c|c|c|c|c|}
\hline $\begin{array}{l}\text { Batch }^{a} \\
{[-]}\end{array}$ & $\begin{array}{l}\mathrm{n} \\
{[-]}\end{array}$ & $\begin{array}{l}\rho_{\mathrm{N}} \\
{\left[\mathrm{kg} / \mathrm{m}^{3}\right]}\end{array}$ & $\begin{array}{l}\mathrm{d} \\
{[\mathrm{mm}]}\end{array}$ & $\begin{array}{l}\mathrm{u}_{\mathrm{gl}} \\
{[\%]}\end{array}$ \\
\hline RV & $30(28)$ & 601 & $6 \times 3$ & 11 \\
\hline RP & $17(15)$ & 599 & $6 \times 3$ & 12 \\
\hline RX & $10(10)$ & 675 & $6 \times 3$ & 12 \\
\hline
\end{tabular}

${ }^{a}$ Explanation: $n$ number of prepared samples. Tested samples with clamping failure are listed in brackets, $R V$ surface perforation by bore hole drillings, $R P$ surface corrugation by punching, $R X$ samples without surface modification, $\rho_{N}$ raw density (mean) of the veneers adjacent to the cement layer, $d$ number of veneer layers $\mathrm{x}$ veneer thickness

(Table 3) and stored again in NC until constant weight for the determination of $\mathrm{u}_{\mathrm{gl}}$ prior to testing.

Batch RP contained the corrugated veneers explained in the previous section (Fig. 6 left). The outer surface of batch RX was unmodified. To investigate the impact of a mechanical "cement-dowelling effect" on the bonding strength between the CLHS and cement, a third series of bore hole drilled hollow sections (batch RV) was produced (Fig. 6 right). Therefore, four rows consisting of clearance holes with $16 \mathrm{~mm}$ in diameter were drilled into the hollow sections. Within a row, the holes had a centre distance of $70 \mathrm{~mm}$ in fiber direction (in pole axis) and $32 \mathrm{~mm}$ centre offset perpendicular to the fiber (peripheral direction). Thus, each CLHS had 16 drillings of $16 \mathrm{~mm}$ diameter. Afterwards, all samples were centrically positioned in a $300 \mathrm{~mm}$ long PVC-tube of $150 \mathrm{~mm}$ in diameter and filled with cement

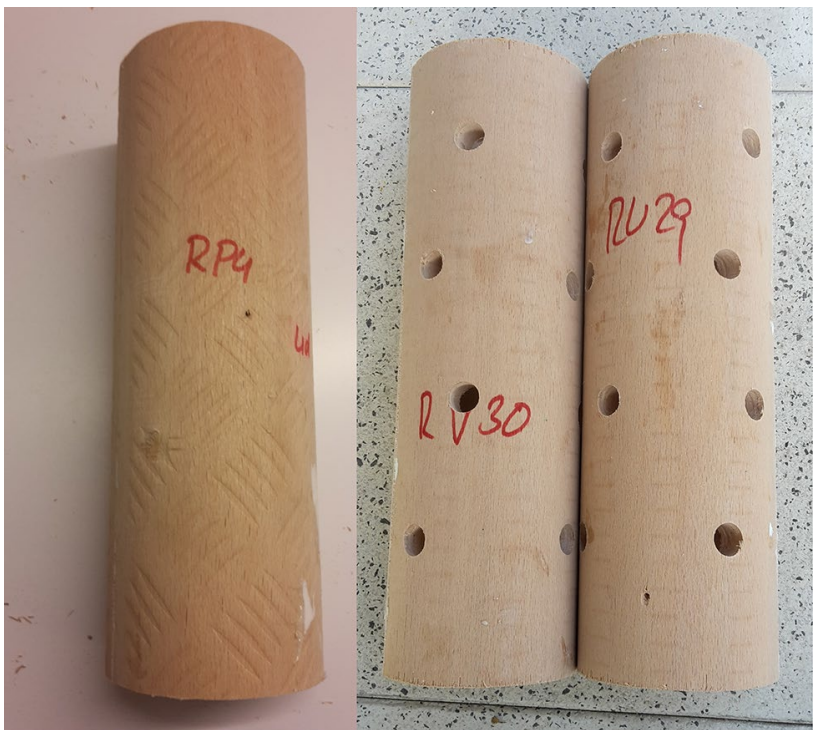

Fig. 6 LVL hollow cross section with veneer surface corrugations (left) and bore hole drillings (right)

CEM II/ A-M (S-LL) $42.5 \mathrm{~N}, \mathrm{w} / \mathrm{c}=0.6$ without any cement additives, a mixture typically used in soil nailing. The end section with the smaller diameter was placed towards the upside to avoid a blocking effect of the grouted CLHS during the push-out tests. After seven days cement setting of the plastic foil covered samples in an environmentally controlled room at NC, the push-out tests were conducted using a $300 \mathrm{kN}$ universal testing machine (Shimadzu) with a deformation-controlled loading rate of $2 \mathrm{~mm} / \mathrm{min}$. The compression load was applied to the protruding end of the CLHS (with completely cement filled core below the bottom of the pressure plate), using a spherical pressure plate in order to compensate for an eccentric loading due to surface irregularities of the loading area. The sample's outer cement body was supported by a circular steel ring at the bottom base of the testing machine, which allowed the setup to develop shear forces in the contact surface between CLHS and surrounding cement body (Fig. 7).

The CLHS surface with cement contact $\mathrm{A}_{\mathrm{CEM}}$ can be noted as

$\mathrm{A}_{\mathrm{CEM}}=\mathrm{D}_{\mathrm{M}} \times \pi \times(\mathrm{L}-\mathrm{dL})$

whereby $\mathrm{dL}$ is the cement settlement due to cement shrinkage and cement compression, taken prior to testing.

\subsubsection{Statistical evaluation of batches}

Scattering material properties of wood demand a statistical evaluation of the test results due to the natural anisotropy and inhomogeneity of wood. Manufacturing, conditioning 


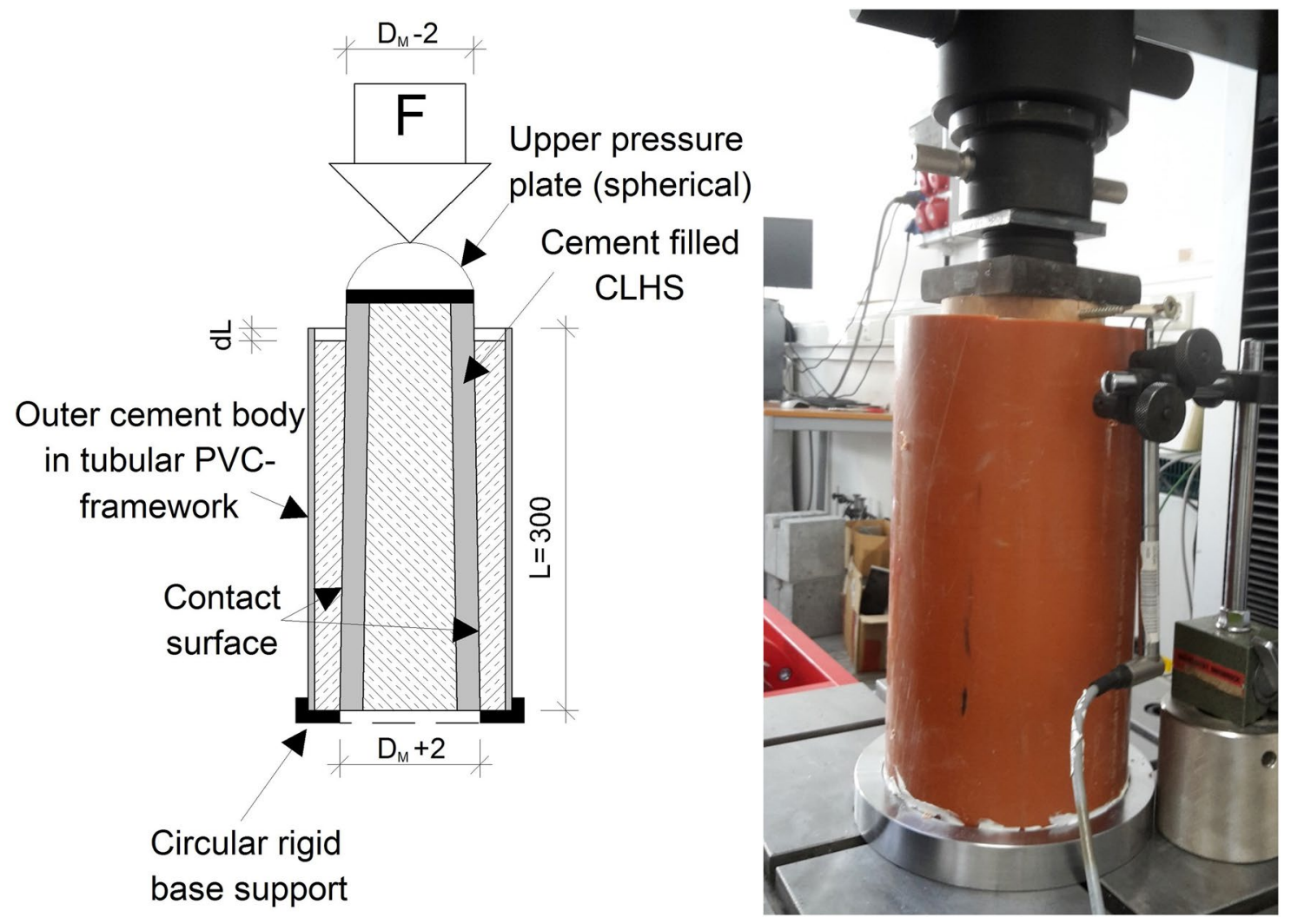

Fig. 7 Schematic of push-out test setup; dimensions in millimetres

and testing costs often are limiting factors for sample sizes, wherefore data has to be described with mathematical probability distributions if a sufficient number of data is not available. Eligible distributions for wood characteristics are inter alia Normal-, Lognormal and Weibull distribution (Pellicane 1985). The first approach is a visual evaluation of boxplot diagrams giving an overview of statistical values and data distribution. Whiskers mark minimum (Min) and maximum (Max) and the distance between Min and Max is described as range $\mathrm{R}$. The lower $\left(\mathrm{Q}_{25}\right)$ and upper $\left(\mathrm{Q}_{75}\right)$ quartiles are described with a box, a horizontal line describes the median ( $\tilde{\mathrm{x}})$ and square in box the arithmetic mean $(\overline{\mathrm{x}})$. A symmetrical configuration of boxplots with a low distance between $\tilde{\mathrm{x}}$ and $\overline{\mathrm{x}}$ indicates normal distribution. More robust tests were to be preferred because of the limited sample sizes $\mathrm{n}$. Therefore, data were tested for normal- or lognormal distribution using a Kolmogorov-Smirnov test at a level of significance of $\alpha=0.05$ in combination with a graphical verification by probability plots. Subsequently, normal- or lognormal distributed data were compared by arithmetic means $\bar{x}$ using a one-way analysis of variance (ANOVA) and a post hoc Tukey's multiple comparison test within each considered group or series, in order to figure out an appropriate surface structure for an effective bonding between CLHS and cement. The test power P is analysed with regard to the reduced sample size and should not be lower than 0.7 to achieve significant differences between the considered batches (Sachs 1993).

For all investigated pull-off and push-out test batches, normal- or lognormal distribution could not be rejected. Generally, the goodness of fit tests were conducted at a level of significance of $\alpha=0.05$. Additionally, the same tests were repeated at level $\alpha=0.01$ in order to increase the significance due to the limited sample size of batches, whereby the same results were obtained.

\section{Results and discussion}

\subsection{Veneer surface topography}

As an advantage of optical surface texture measurements, three-dimensional surface parameters (defined in EN ISO 25,178-2: 2012) can be determined in addition to linear roughness characteristics. Using the arithmetic mean roughness $\mathrm{P}_{\mathrm{a}}$ (unfiltered primary profile) or the average peak-tovalley height $\mathrm{P}_{Z}$, determined compliant to EN ISO 4287 (1998), as decisive surface characteristic, the veneer surface corrugation as a geometrical surface shape deviation of second order (defined in DIN 4760: 1982) is considered, 
as the waviness is not suppressed through a Gaussian filter. An additional and more distinctive method to compare the surface roughness of differently treated veneer sheets is to determine the veneer samples' true surface area $A_{r}$ in relation to the projected surface area $A_{p}$ (Fig. 8), combining both, surface waviness of second order and surface roughness of higher orders. $A_{r} / A_{p}$ of the samples with an unmodified surface (Fig. 9, batch UM1) is significantly higher compared to the samples with a punched surface. Beside a macroscopic surface corrugation effect, the aluminium plate is assumed to equalize the surface on a microscopic scale during the pressing process, which might explain the lower ratios $A_{\mathfrak{l}} / A_{p}$ of modified samples.

The indication of a surface equalization, caused by the aluminium plate, additionally is supported by the measured arithmetic mean roughness $\mathrm{P}_{\mathrm{a}}$ in combination with the average surface roughness $\mathrm{P}_{Z}$ (Fig. 9). $\mathrm{P}_{\mathrm{a}}$ of all six batches does not differ significantly, although $\mathrm{P}_{\mathrm{a}}$ of batch UM1 reveals a larger scattering. The definition of an arithmetic mean roughness is based on a rough averaging, which normally is reflected in a low scattering of values. Additionally, using the arithmetic mean roughness, it cannot be distinguished between surface peaks and valleys, and profiles such as corrugations pressed onto the surface are not recognized.

\subsection{Veneer surface soundness}

Some samples failed before the pull-off forces could be measured due to sample manipulation during the clamping process prior to testing. This explains the difference between the number of prepared samples and the number of tested samples (Table 2). Although for all batches normal and lognormal distribution of the measured pull-off forces could not be rejected, a classification of the different modification methods of veneer and cement has to be done carefully due to the low number of valid samples and the high scattering results with a coefficient of variation (COV) up to $90 \%$ (Table 4). A statistical outlier test (Grubb's test) identified at a level of significance of $\alpha=0.05$ no outlier in any of the batches. Using a one-way ANOVA and a post hoc Tukey's multiple comparison test, within each group no significant difference of means, neither at a level $\alpha=0.05$ nor at $\alpha=0.01$, could be observed. Within those tests, a significant influence of setting accelerator addition to the cement on the surface soundness (group 1) between beech LVL and cement (CEM II/A-M (S-LL) $42.5 \mathrm{~N}$ ) could not be proven. Though receiving statistically conclusive results with $\mathrm{P}>0.7$, a hypothetical sample size of $n>200$ would be required, compared to the existing low test power $(\mathrm{P}=0.2)$. Varying the wood
Fig. 8 Optically processed surface area $A_{r}$ of a veneer sheet with visualized corrugation structure (bright area) and projected bottom and top surface $\mathrm{A}_{\mathrm{p}}$ (circumscribing box)

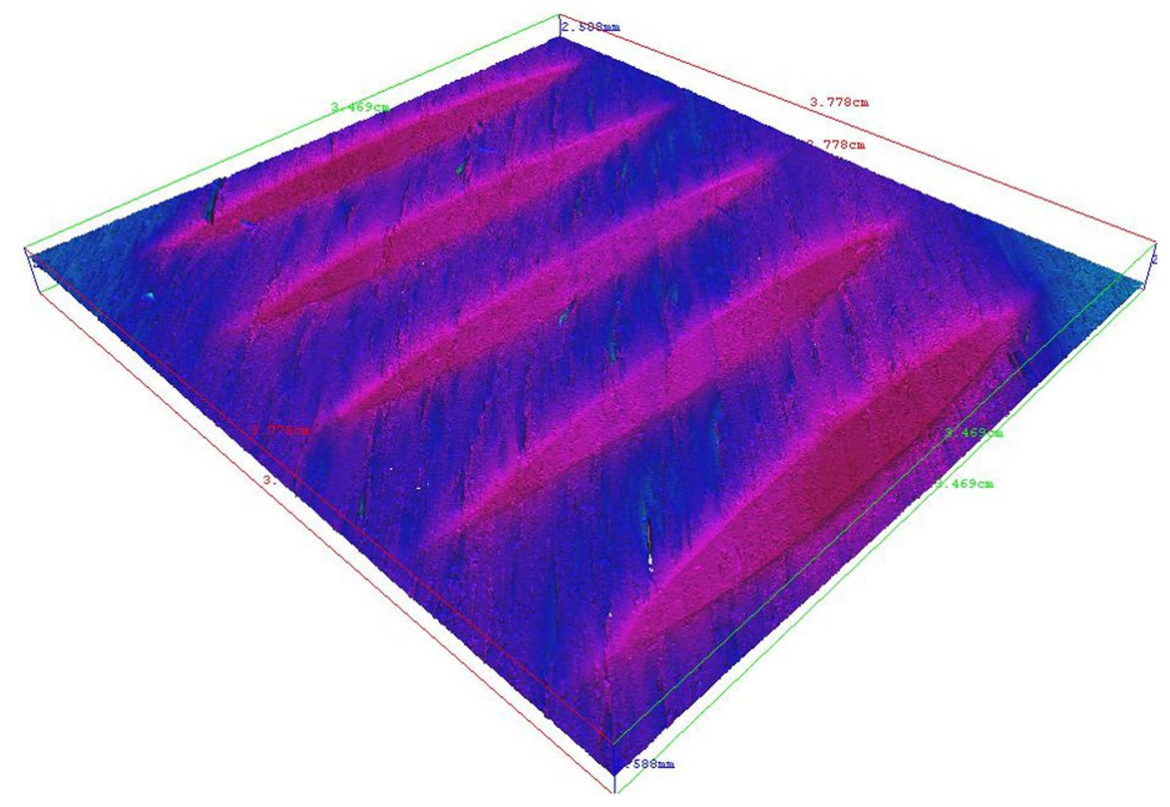

Height Subrange

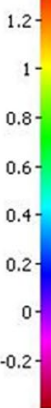

However, the considerably larger $\mathrm{P}_{\mathrm{a}}$ scattering of batch UM1 indicates the presence of an unequalised surface with a naturally high scattering. Contrary, the average peak-to-valley height $\mathrm{P}_{\mathrm{Z}}$ (arithmetic mean of the height differences of the highest peak and the lowest valley within a specific calibration distance) reacts more sensitive to the change in surface profiles, and the pressed corrugation is recognized. moisture content at a level of $4 \% \mathrm{MgCl}_{2} \cdot 6 \mathrm{H}_{2} \mathrm{O}$ addition to the cement, batch 5 with a relatively low $\mathrm{MC}$ of $\mathrm{u}_{\mathrm{gl}}=11 \%$ showed significantly higher results compared to the batches with higher MC (Fig. 10). Noticeable is the surface structure influence, comparing batch 4 and batch 5 in pairs by a t-test with Welch-correction for two independent samples with unequal variances. Both have the same amount of added cement setting accelerator and the same MC, but different 


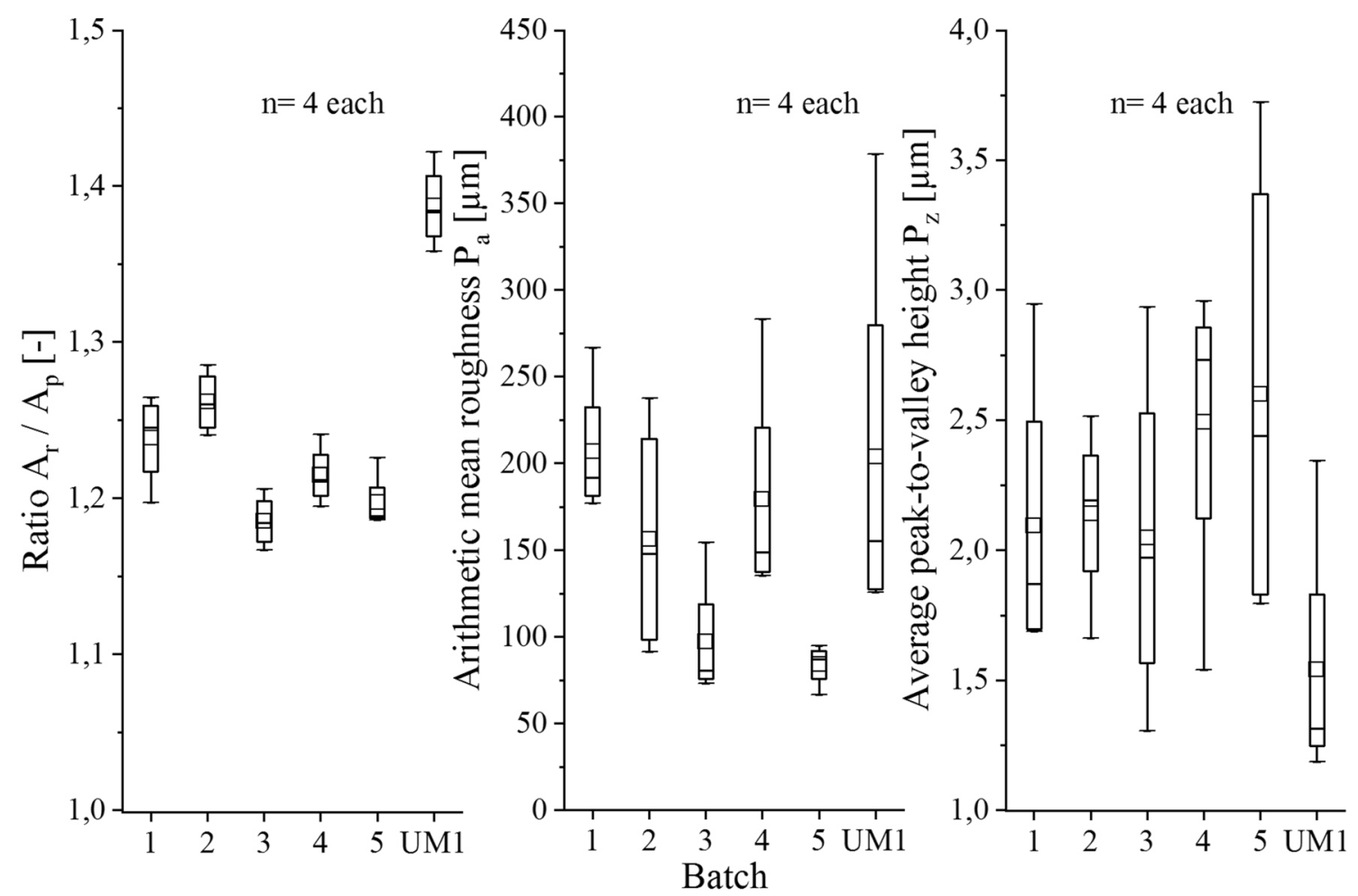

Fig. 9 Surface topography parameters of four randomly chosen samples per batch; Whiskers minimum and maximum values, box $\mathrm{Q}_{25^{-}}$and $\mathrm{Q}_{75^{-}}$ quartile, square in box arithmetic mean, $n$ number of samples and horizontal line median

Table 4 Pull-off forces

\begin{tabular}{|c|c|c|c|c|c|c|c|}
\hline \multirow[t]{2}{*}{ Feature batch } & \multicolumn{2}{|c|}{ Group } & \multirow{2}{*}{$\begin{array}{l}\bar{x} \\
{[N]}\end{array}$} & \multirow{2}{*}{$\begin{array}{l}\text { SD } \\
{[N]}\end{array}$} & \multirow{2}{*}{$\begin{array}{l}\mathrm{COV} \\
{[\%]}\end{array}$} & \multirow{2}{*}{$\begin{array}{l}\tilde{x} \\
{[N]}\end{array}$} & \multirow{2}{*}{$\begin{array}{l}\mathrm{R} \\
{[\mathrm{N}]}\end{array}$} \\
\hline & {$[-]$} & & & & & & \\
\hline 1 & 1 & Planed surface & 0.9 & 0.5 & 48 & 1.1 & 1.1 \\
\hline 2 & & & 1.4 & 1.2 & 81 & 0.8 & 2.7 \\
\hline 3 & & & 1.3 & 0.5 & 38 & 1.2 & 1.2 \\
\hline 4 & & & 1.6 & 1.4 & 88 & 1.4 & 4.4 \\
\hline 5 & 2 & Rough surface & 4.8 & 2.3 & 48 & 3.9 & 8.3 \\
\hline 6 & & & 2.0 & 1.7 & 83 & 1.7 & 5.8 \\
\hline 7 & & & 4.1 & 3.8 & 92 & 2.8 & 12.5 \\
\hline 8 & REF & Spruce & 36.0 & 23.2 & 64 & 28.4 & 85.2 \\
\hline
\end{tabular}

surface structures. While the pull-off forces of the planed surfaces of batch 4 were rather low, the significantly higher average forces of batch 5 with rough surfaces were approximately three times higher, which indicates a greater influence of surface structure on bonding strength than cement setting acceleration or wood moisture modification. A great influence of wood species and the soluble saccharide on the bonding behaviour between wood and cement was observed. The tested spruce reference batches with planed surface showed an approximately 10 times higher bonding strength (force $\mathrm{F}_{\text {eff }}$ referred to $\mathrm{A}_{\mathrm{CEM}}$ ) than beech veneers under the same testing conditions (Fig. 11). These results go in line with data published in Simatupang (1986), where hydration tests of cement upon timber boards after $48 \mathrm{~h}$ cement setting revealed ten times more loose cement particles of native beech wood samples compared to spruce. Publications on pull-off test of wood-cement composites are rather rare. Although the published data are not satisfyingly comparable to the investigated spruce reference batch REF SP due to the different contact surface $\mathrm{A}_{\mathrm{CEM}}$, the cement composition and the cement setting time (Table 2), they reveal a good confirmation of the test setup accuracy as they are within a similar order of magnitude. The rougher surface and the lower cement content in cement mortar compared to pure cement and, therefore, a decreased ability of dissolving saccharide, are assumed to be possible reasons for their higher 
Fig. 10 Pull-off forces perpendicular to the surface of group 1 (left) and group 2 (right); Whiskers minimum and maximum values, box $\mathrm{Q}_{25}$ - and $\mathrm{Q}_{75^{-}}$quartile, square in box arithmetic mean $n$ number of tested samples and horizontal line median

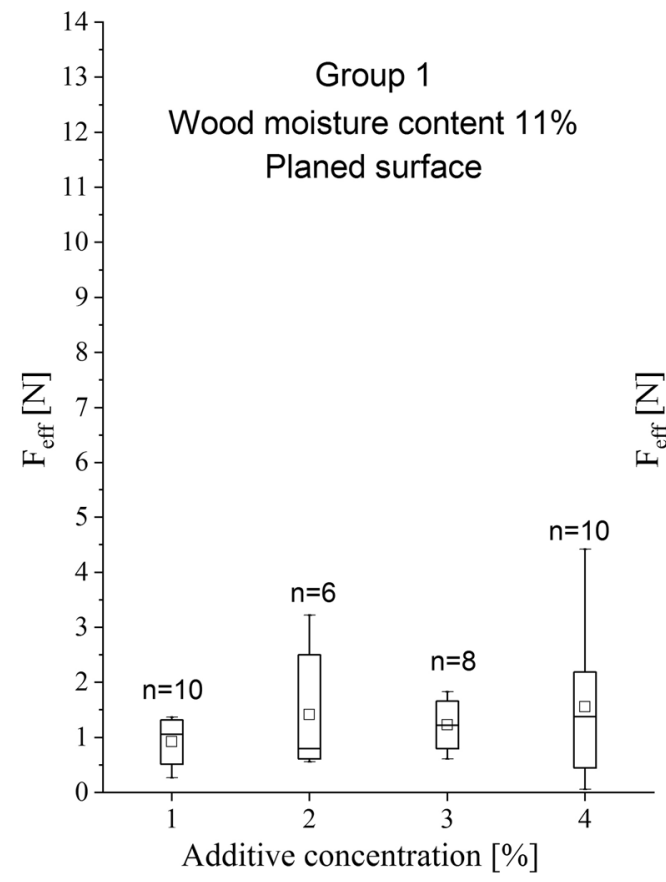

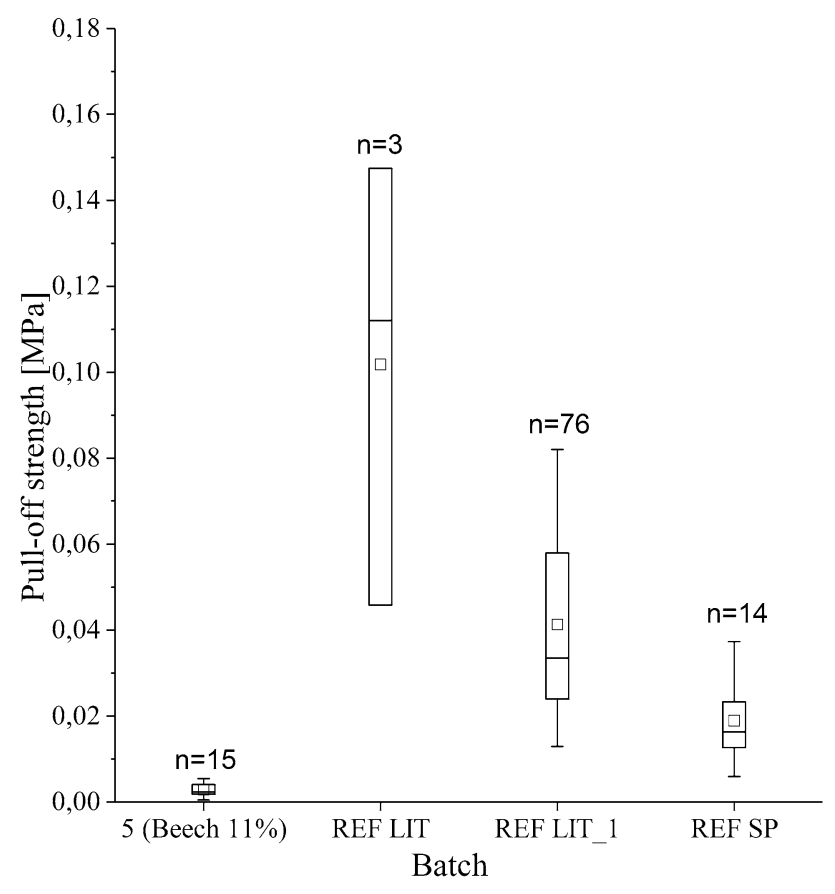

Fig. 11 Pull-off strength of batch 5 compared to spruce reference batches. Whiskers minimum and maximum values, box $\mathrm{Q}_{25^{-}}$and $\mathrm{Q}_{75^{-}}$ quartile, square in box arithmetic mean, $n$ number of samples and horizontal line median

bonding strength. To summarize, the wood species has the highest influence on the pull-off strength due to the higher content of hydration inhibiting saccharide in beech compared to spruce. An increased addition of a cement setting accelerator $\left(\mathrm{MgCl}_{2} \cdot 6 \mathrm{H}_{2} \mathrm{O}\right)$ in proportions of $1-4 \%$ does not overcome the inhibiting effect to the same extent as surface roughness, whereby samples with a lower MC reveal the highest pull-off results.

\subsection{Ultimate shear strength between CLHS and cement body}

To compare the ultimate shear strength $\tau_{\max }$ of the different CLHS surface modifications, the maximum applied compressive load $\mathrm{F}_{\max }$ was determined at the first peak of the force $F_{\max }$-displacement $\delta_{\mathrm{u}}$ curve (Fig. 12), at the onset of a slip displacement with subsequent abrupt force reduction. After testing, four samples had to be removed from the result analysis (Table 3) due to an incorrect positioning of the CLHS within the tube. The eccentric position caused a contact between CLHS and the bottom support ring and therefore impeded a push-out failure. As there was no displacement transducer used, the displacement between wood member and surrounding cement body was determined by machine stroke. The completely filled cement core of the CLHS reduced the distortion of displacement results caused by plastic material deformation at the loading point. Hence, the load displacement curve delivers sufficient qualitative information about the bonding behaviour during the loading process, but the absolute values have to be taken with caution due to the material flexibility of the cement filled CLHS and the cement body. For all samples, after a short setting phase of the spherical pressure plate, an approximately linear force increase with low displacements until brittle failure with rapid force reduction and subsequent slip deformation was observed. Although the measured force-displacement 


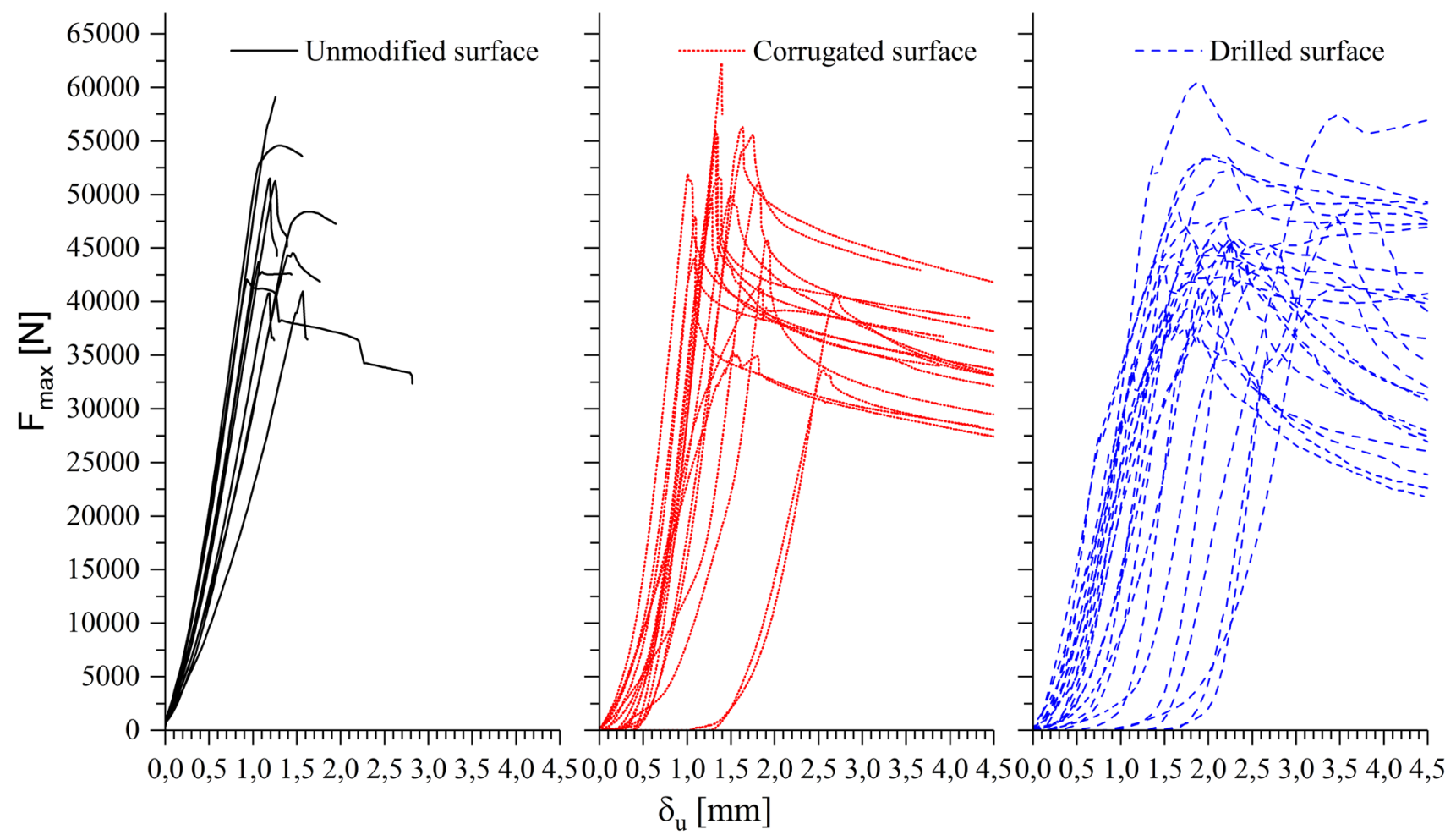

Fig. 12 Push-out tests, force - displacement curves of batches RX (left), RP (centre) and RV (right)

curves cannot be divided into phases similar to reinforcement in concrete (Gambarova et al. 1989a, b), due to the linear force increase with subsequent brittle failure, the displacements $\delta_{\mathrm{u}}$ between $1 \mathrm{~mm}$ and $1.5 \mathrm{~mm}$ (without initial setting phase) are similar to pull-out measurements of steel reinforcement in concrete published in Gambarova et al. (1989a) and Ritter (2013). Therefore, the similarly low slip displacements $\delta_{u}$ between CLHS and cement body justify a rigid consideration of the bond. The maximum loading results were normalized by calculating the ultimate shear strength $\tau_{\max }$ as the ratio of maximum load to the surface area with cement contact due to the varying bonding length $\mathrm{dL}$ of the different samples. For simplification, $\tau_{\max }$ is assumed to be uniformly distributed through (L-dL).

$\tau_{\max }=\frac{F_{\max }}{D_{M} \times \pi \times(L-d L)}$

For RSW design, the mobilization of lateral friction $\mathrm{T}_{\mathrm{L}}$ along the nails is decisive and has to be practically verified for each RSW through the construction process by in situ pull-out tests compliant to EN 14490 (2010). $\mathrm{T}_{\mathrm{L}}$ is referred to the nail's anchorage length in the passive soil body and therefore normalized by unit per length, as an exact determination of the cement body's outer diameter is impossible during the RSW construction. The ultimate shear flow $\mathrm{T}_{\max }$ can be calculated as
$\mathrm{T}_{\max }=\frac{\mathrm{F}_{\max }}{(\mathrm{L}-\mathrm{dL})}$

Since a Kolmogorov-Smirnov test at a level of significance of $\alpha=0.05$ revealed normal distributed data for all batches, a one-way ANOVA and a post hoc Tukey's test was used for data comparison. A strong test power $(\mathrm{P}=0.79)$ indicated a sufficient number of samples. The arithmetic mean $\bar{\tau}_{\text {max }}$ between samples with a punched surface (batch RP) and drilled samples (batch RV) differed significantly, although no significant difference between the other batches was recognized. The ultimate shear strength (Fig. 13) of unmodified samples was not significantly lower than the average mean of batch RP, but also not significantly higher than batch RV, which goes in line with the results of the optical surface texture measurements. Surface punching of the veneers does not significantly increase the veneer surface and therefore the ultimate shear strength between CLHS and cement body. The corrugations have a negligible influence on the bond between wood surface and cement, due to the large initial surface of rough veneers and the opened veneer peeling cracks due to the veneer curvature.

\subsection{Characteristic shear force for soil nailing design}

The characteristically transferable shear force between soil and nail is a decisive value for internal stability design of 


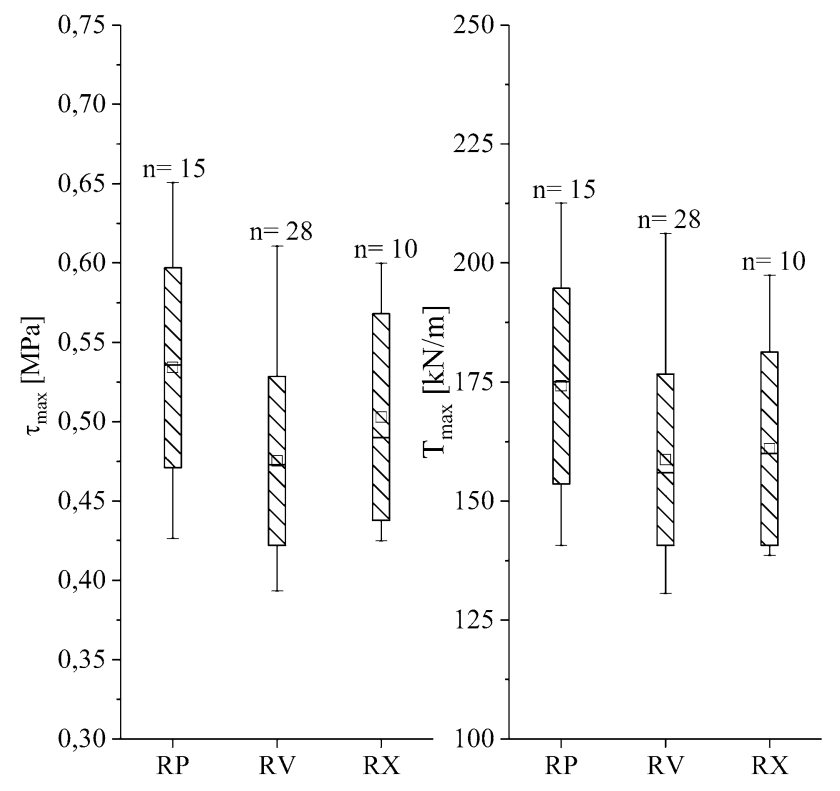

Fig. 13 Ultimate shear strength (left) and ultimate shear flow (right) between CLHS and cement body. Whiskers minimum and maximum values, box Q25- and Q75- quartile, square in box arithmetic mean, $n$ number of samples and horizontal line median

RSWs and depends inter alia on soil properties, nail position and construction quality. It is assumed that the load is uniformly distributed through the bonded length. The design methods of an RSW consider a rigid bond between steel reinforcement and grout, as the connection between soil and grout is the weakest link within the nail -cementsoil system in general. Published results of concrete-reinforcement pull-out tests (Ritter 2013; Simons 2007) reveal a pull-out strength between reinforcement tendon and concrete by at least a decimal power higher compared to the results presented in Fig. 13. Technical approvals of soil nails (BMVIT-327.120/0012-IV/ST2/2015, 2015) specify $5.1 \mathrm{MPa}$ as the characteristic bonding strength, determined by pull-out tests. As mentioned previously in this paper, the characteristic mobilized skin friction between soil and nail, $\tau_{\mathrm{k}, \mathrm{m}}$ or $\mathrm{T}_{\mathrm{k}, \mathrm{m}}$ respectively, has to be verified through pullout tests and is, depending on the number of tested nails, reduced by a scattering factor $1 \leq \xi \geq 1.05$ compliant to ÖNORM B 1997-1-1 (2013). Therefore, the RSW design depends on in situ determined ultimate bond stresses $\tau_{\max }$ $\left(\mathrm{T}_{\max }\right)$, whereby values $\tau_{\max }$ between 0.1 and $0.4 \mathrm{MPa}$ can be found in the literature (Lazarte 2011; Williams and Yang 2014), which are within the same scale as the results given in Fig. 13. The characteristic bonding strength between CLHS and cement body is calculated compliant to EN 14358: 2016 at a confidence level of $(1-\alpha)=0.75$ and a proportion of $\gamma=0.95$, assuming lognormal distributed data and an unknown population mean (Klöck 2004).
Table 5 Characteristic shear strength between CLHS and cement body

\begin{tabular}{llllll}
\hline $\begin{array}{l}\text { Batch }^{\mathrm{a}} \\
{[-]}\end{array}$ & $\begin{array}{l}\mathrm{n} \\
{[-]}\end{array}$ & $\begin{array}{l}\overline{\bar{\tau}}_{\max } \\
{[\mathrm{MPa}]}\end{array}$ & $\begin{array}{l}\mathrm{k}_{\mathrm{S}}(\mathrm{n}) \\
{[-]}\end{array}$ & $\begin{array}{l}\mathrm{SD} \\
{[\mathrm{MPa}]}\end{array}$ & $\begin{array}{l}\tau_{\mathrm{k}, \mathrm{m}} \\
{[\mathrm{MPa}]}\end{array}$ \\
\hline $\mathrm{RV}$ & 28 & 0.48 & 1.878 & 0.05 & 0.39 \\
$\mathrm{RP}$ & 15 & 0.53 & 1.991 & 0.06 & 0.42 \\
$\mathrm{RX}$ & 10 & 0.50 & 2.104 & 0.07 & 0.38 \\
\hline
\end{tabular}

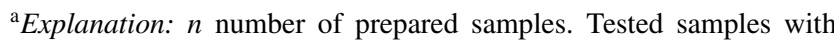
clamping failure are listed in brackets, $R V$ surface perforation by bore hole drillings, $R P$ surface corrugation by punching, $R X$ samples without surface modification, $\rho_{N}$ raw density (mean) of the veneers adjacent to the cement layer, $d$ number of veneer layers $\mathrm{x}$ veneer thickness

$\ln \tau_{\mathrm{k}, \mathrm{m}}=\mathrm{e}^{\bar{\tau}_{\max }-\mathrm{k}_{\mathrm{s}}(\mathrm{n}) \times \mathrm{SD}}$

whereby $\mathrm{k}_{\mathrm{S}}(\mathrm{n})$ is defined as

$\mathrm{k}_{\mathrm{S}}(\mathrm{n})=\frac{\mathrm{k}_{\alpha}(\mathrm{n})}{\sqrt{\mathrm{n}}}$

Herein $k_{\alpha}(n)$ is a statistical factor for the calculation of one-sided tolerance intervals depending on the sample size n. Further information about the detailed calculation of characteristic material strength and values for $\mathrm{k}_{\alpha}(\mathrm{n})$ are given in Klöck (2004). In Table 5, the calculated characteristic shear strength between the CLHS and the cement composite is given. The characteristic shear strength between CLHS and cement body is in the upper range of values for the mobilized skin friction between cement grout and soil as mentioned before.

\section{Conclusion}

The presented results show a sufficient bonding behaviour between beech CLHS and cement CEM II/ A-M (S-LL) $42.5 \mathrm{~N}$, typically used in practical soil nailing. In contrast to previous publications, the addition of a cement setting accelerator $\left(\mathrm{MgCl}_{2} \cdot 6 \mathrm{H}_{2} \mathrm{O}\right)$ does not influence the bond between beech and cement to the extent that surface roughness and wood moisture content do. Surface roughness has a substantial effect on bonding strength, whereby punched corrugations and drillings do not improve the bond due to the rough surface of peeled veneers with peeling cracks at the core side of the veneer. Push-out tests of CLHS with unmodified wood surface in contact with CEM II/A-M (S-LL) $42.5 \mathrm{~N}$ $(\mathrm{w} / \mathrm{c}=0.6)$ reveal a sufficient characteristic shear strength between wood and the surrounding cement body for the use in soil nailing applications. However, the low strength compared to steel reinforcement bars can be a decisive factor in soil nailing design, especially for reinforcement elements in 
densely layered soils with high shear strength or rocks and therefore a highly mobilized skin friction between cement grout and soil. No loss of contact between CLHS and cement was observed during the push-out tests. However, in future research on time and moisture depending cement and wood shrinkage, swelling stresses in the contact surface (depending on the stiffness of the outer sheath) and its influence on the bond between CLHS and cement annulus are necessary. The presented results reveal a short-term material behaviour and therefore have to be validated through long-term tests in order to avoid bond failure due to wood creeping effects and alkaline wood degradation. The influence of non-linear (cement shrinkage) deformations may have a significant influence on the friction between wood surface and cement annulus, as differential deformations between the surfaces may lead to a failure due to contact loss.

Acknowledgements The authors would like to thank Mr. Peter Kamm for his great efforts carrying out the preliminary pull-off tests within his bachelor thesis.

Funding Open Access funding enabled and organized by Projekt DEAL. The research was supported by the German Federal Ministry of Education and Research (Grant Number 13FH022IX4).

Open Access This article is licensed under a Creative Commons Attribution 4.0 International License, which permits use, sharing, adaptation, distribution and reproduction in any medium or format, as long as you give appropriate credit to the original author(s) and the source, provide a link to the Creative Commons licence, and indicate if changes were made. The images or other third party material in this article are included in the article's Creative Commons licence, unless indicated otherwise in a credit line to the material. If material is not included in the article's Creative Commons licence and your intended use is not permitted by statutory regulation or exceeds the permitted use, you will need to obtain permission directly from the copyright holder. To view a copy of this licence, visit http://creativecommons.org/licenses/by/4.0/.

\section{References}

Azadeh A, Kazemi HH (2014) New approaches to bond between bamboo and concrete. KEM 600:69-77. https://doi.org/10.4028/www. scientific.net/KEM.600.69

BMVIT-327.120/0012-IV/ST2/2015 (2015) DYWI® Drill HohlstabSystem (DYWI® Drill hollow bolts). Ministry for Transport. Innovation and Technology, Vienna

DIN 4760 (1982) Gestaltabweichungen, Begriffe-Ordnungssystem (Form deviation, waviness, surface roughness; system of order, terms and definitions). German Institute for Standardization, Berlin

EN 1386 (2007) Aluminium and aluminium alloys-tread platespecifications. European Committee for Standardization, Brussels

EN 14358 (2016) Timber structures - calculation and verification of characteristic values. European Committee for Standardization, Brussels

EN 14490 (2010) Execution of special geotechnical works-soil nailing. European Committee for Standardization, Brussels
EN 206 (2016) Adhesives—wood adhesives for non-structural applications-determination of tensile shear strength of lap joints. European Committee for Standardization, Brussels

EN 311 (2002) Wood-based panels-surface soundness-test method. European Committee for Standardization, Brussels

EN 635-2 (1995) Plywood-classification by surface appearancePart 2: hardwood. European Committee for Standardization, Brussels

EN ISO 4287 (1998) Geometrical product specifications (GPS)-surface texture: profile method-terms, definitions and surface texture parameters. European Committee for Standardization, Brussels

EN ISO25178-2 (2012) Geometrical product specifications (GPS)-Surface texture: Areal-Part 2: terms, definitions and surface texture parameters. European Committee for Standardization, Brussels

Gambarova PG, Rosati GP, Zasso B (1989a) Steel-to-concrete bond after concrete splitting: Constitutive laws and interface deterioration. Mater Struct 22:347-356. https://doi.org/10.1007/BF024 72505

Gambarova PG, Rosati GP, Zasso B (1989b) Steel-to-concrete bond after concrete splitting: test results. Mater Struct 22:35-47. https ://doi.org/10.1007/BF02472693

Glaus MA, van Loon LR, Achatz S, Chodura A, Fischer K (1999) Degradation of cellulosic materials under the alkaline conditions of a cementitious repository for low and intermediate level radioactive waste. Anal Chim Acta 398:111-122. https://doi.org/10.1016/ S0003-2670(99)00371-2

Hirschmüller S, Marte R, Pravida J (2016) Laminated veneer lumber poles for temporary soil nailing - investigation of material properties. In: Eberhardsteiner J, Winter W, Fadai A, Pöll M (eds) WCTE 2016: Proceedings of the World Conference on Timber Engineering. Vienna University of Technology, Vienna

Hirschmüller S, Pravida J, Marte R, Flach M (2018a) Adhesive properties of laminated veneer lumber poles for use in temporary soil nailing: Development and evaluation of a test method for curved structures in a high-alkaline environment. Wood Sci Technol 54:1061-1092. https://doi.org/10.1007/s00226-018-0997-y

Hirschmüller S, Pravida J, Marte R, Flach M (2018b) Long-term material properties of circular hollow laminated veneer lumber sections under water saturation and cement alkaline attack. Wood Mat Sci Eng 81:1-15. https://doi.org/10.1080/17480272.2018.1434830

Klatt A (2012) Mineralisch ummantelte Holzspäne als Leichtzuschlag für Beton; Potentiale und Grenzen modifizierter organischer Materialien (Mineral-coated wooden chips as lightweight concrete aggregate; Potential and limitations of modified organic materials). $\mathrm{PhD}$ thesis, TU Darmstadt

Klingsch E, Klippel M, Boccadoro L, Frangi A, Fontana M (2015) Brandverhalten von Holz-Beton-Verbunddecken aus Buchenholz (Fire behaviour of timber-concrete composite slabs using beech). Bautechnik 92:323-329. https://doi.org/10.1002/bate.201500014

Klöck W (2004) Determination of characteristic values for structural timber. Otto-Graf-J 15:43-58. https://www.mpa.uni-stuttgart.de/ institut/publikationen/otto-graf-journal/new_downloadgallery /2004/2004_beitrag_kloeck.pdf

Knill CJ, Kennedy JF (2003) Degradation of cellulose under alkaline conditions. Carbohyd Polym 51:281-300. https://doi.org/10.1016/ S0144-8617(02)00183-2

Lazarte CA (2011) Proposed specifications for LRFD soil-nailing design and construction. NCHRP report, vol 701. Transportation Research Board, Washington

Leach R (2011) Optical measurement of surface topography. SpringerVerlag, Berlin

Lehmann S (2005) Untersuchungen zur Bewertung von Verbundbauteilen aus Brettstapelelementen im Flächenverbund mit mineralischen Deckschichten (Investigations for the evaluation of composite elements made of raftered decks in adhesive bond with mineral overlays). PhD thesis, Bauhaus-Universität Weimar 
Lopez-Anido RA, Michael AP, Sandford TC (2004) Fiber-reinforced polymer composite-wood pile interface characterization by pushout tests. Maine sea grant, MSG-R-04-11. American Society of Civil Engineers, New York

Mašura V (1982) Alkaline degradation of spruce and beech wood. Wood Sci Technol 16:155-164. https://doi.org/10.1007/BF003 51100

Nwaogu UC, Tiedje NS, Hansen HN (2013) A non-contact 3D method to characterize the surface roughness of castings. J Mater Process Technol 213:59-68. https://doi.org/10.1016/j.jmatprotec .2012 .08 .008

ÖNORM B 1997-1-1 (2013) Eurocode 7: geotechnical design-Part 1: general rules-national specifications concerning ÖNORM EN 1997-1 and national supplements. European Committee for Standardization, Vienna

Pellicane PJ (1985) Goodness-of-fit analysis for lumber data. Wood Sci Technol 19:117-129. https://doi.org/10.1007/BF00353072

Ritter L (2013) Der Einfluss von Querzug auf den Verbund zwischen Beton und Betonstahl (Influence of transverse tension on bond behaviour between concrete and reinforcing steel). Dissertation, Technische Universität Dresden

Sachs L (1993) Statistische Methoden; Planung und Auswertung (Statistical methods; planning and evaluation), 7th revised edition. Springer-Verlag, Berlin

Schober K-U (2008) Untersuchungen zum Tragverhalten hybrider Verbundkonstruktionen aus Polymerbeton, faserverstärkten Kunststoffen und Holz (Composite constructions of polymer-concrete, fiber-reinforced plastic and timber). Schriftenreihe des Instituts für Konstruktiven Ingenieurbau, vol 17. Universitätsverlag Bauhaus Universität, Weimar

Schubert B, Wienhaus O, Bloßfeld O (1990a) Untersuchungen zum System Holz-Zement: Einfluss unterschiedlicher Holzarten auf das Abbindeverhalten von Holz-Zement-Mischungen und Möglichkeiten zur Modifizierung des Systems (Investigation of woodcement interaction: Influence of different cements on the setting behaviour of wood - cement composites and possibilites of system modification). Holz Roh- Werkst 48:423-428. https://doi. org/10.1007/BF02627624

Schubert B, Wienhaus O, Bloßfeld O (1990b) Untersuchungen zum System Holz-Zement: Einfluss unterschiedlicher Zementarten auf das Abbindeverhalten von Holz-Zement-Mischungen (Investigation of wood-cement interaction: Influence of different cements on the setting behaviour of wood - cement composites). Holz RohWerkst 48:185-189. https://doi.org/10.1007/BF02617774

Schwarz HG, Simatupang MH (1984) Eignung des Buchenholzes zur Herstellung zementgebundener Holzwerkstoffe (Suitability of beech for the production of cement-bonded wooden products). Holz Roh- Werkst 42:265-270. https://doi.org/10.1007/BF026 07194

Simatupang MH (1986) Abbaureaktionen von Glucose, Cellobiose und Holz unter dem Einfluß von Portlandzementmörtel (Degradation of glucose, cellobiose and wood under the influence of Portland cement). Holzforschung 40:149-155

Simons IN (2007) Verbundverhalten von eingemörtelten Bewehrungsstäben unter zyklischer Beanspruchung (Bonding behaviour of grouted reinforcement bars under cyclic loading). $\mathrm{PhD}$ thesis, Universität Stuttgart

Tamburini U (1970) Alkaline degradation of wood: effects on Young's modulus. Wood Sci Technol 4:284-291. https://doi.org/10.1007/ BF00386404

Unterberger SH (2014) Ein Beitrag zum Abzugsverhalten zwischen zementgebundenen Materialien und Schalhaut (A contribution to the pull-off behaviour between cement-bound materials and formwork). $\mathrm{PhD}$ thesis, Universität Innsbruck

Wei YM, Guang Zhou Y, Tomita B (2000) Hydration behavior of wood cement-based composite I: evaluation of wood species effects on compatibility and strength with ordinary Portland cement. J Wood Sci 46:296-302. https://doi.org/10.1007/BF00766220

Wei YM, Zhou YG, Tomita B (2000) Study of hydration behavior of wood cement-based composite II: Effect of chemical additives on the hydration characteristics and strengths of wood-cement composites. J Wood Sci 46:444-451. https://doi.org/10.1007/ BF00765802

Williams JA, Yang L (2014) Ultimate bond stresses from pull out testing of soil nails, Dinmore to Goodna, SE-QLD. Aust Geomech 49:79-88

Zilch K, Zehetmaier G (2010) Bemessung im konstruktiven Betonbau: Nach DIN 1045-1 (Fassung 2008) und EN 1992-1-1 (Eurocode 2). (Design of concrete works compliant with DIN 1045-1 and EN 1992-1-1). Springer-Verlag, Berlin 